УДК $327.8: 327.2$

\title{
ОСОБЛИВОСТІ ПРИМИРЕННЯ ТА ЙОГО ПЕРСПЕКТИВИ НА РІЗНИХ СТАДІЯХ НАСИЛЬНИЦЬКОГО КОНФЛІКТУ
}

\section{Семчинський Костянтин Валерійович}

кандидат філософських наук, доцент, Київський університет культури, м. Київ, Україна ORCID: 0000-0002-3125-3401 semchynskyy@gmail.com

Визначення перспектив примирення на різних стадіях насильницького конфлікту постає наразі актуальним питанням, оскільки вже під час конфлікту закладаються підвалини пост-конфліктного врегулювання, від якого залежить ефективність примирення та можливість розбудови миру в майбутньому. Метою роботи є дослідження особливостей взаємодії як між сторонами впродовж глибинного міждержавного конфлікту, так і між сторонами впродовж громадянського конфлікту в межах держави. Застосувавши системні, аналітичні і компаративні методи, автор характеризує політичне примирення як довготривалий суспільно-інклюзивний процес, який покликаний трансформувати невдоволене співіснування сторін конфлікту у спільну політичну участь у суспільних інституціях і політичних процесах за допомогою поступового виховання поваги як до нових інституцій, так і до колишніх ворогів. Чотири складові примирення - мир, справедливість, правда і прощення, - мають бути взаємопов'язані в цьому процесі. У результаті дослідження автор визначає обов'язковими елементами взаємодії між сторонами впродовж і після насильницького конфлікту суспільно-психологічні засоби сприйняття i трактування минулого та майбутнього, розбудову позитивних відносин і переформатування в них культурно-ціннісної парадигми, а також трансформацію соціально-економічної реальності. У висновках виявлено, що ідеальної моделі чи досконалого методу примирення після насильницького конфлікту не існує, тому у кожному конкретному випадку особливості примирення залежать від здатності сторін творчо та ефективно підходити до процесу примирення, від їхньої здатності консолідовано прийняти втрати, жорстокість і біль минулого задля перспектив спільного майбутнього. Водночас, автор робить висновки про те, що перспективи примирення впродовж і після завершення насильницького конфлікту визначаються практичним проявом співробітництва та створенням 
надійних запобіжників проти рецидиву конфлікту в майбутньому задля розбудови стійкого і тривалого позитивного миру між сторонами.

Ключові слова: конфлікт; примирення; політичний процес; розбудова миру; суспільство; насильство.

Semchynskyi Kostiantyn, Ph. D. in Philosophy, Associate Professor, Kyiv University of Culture, Kyiv, Ukraine

Features of reconciliation and its perspectives in various stages of the violence conflict

Identifying the prospects of reconciliation at various stages of the violent conflict is a matter of urgent concern, since during the conflict the foundations of a post-conflict settlement are laid down, the effectiveness of reconciliation and the possibility of building peace in the future depend on. The purpose of the work is to study the peculiarities of interaction between the parties during the deep interstate conflict and between the parties during the civil conflict within the state. Applying systematic, analytical and comparative methods, the author characterizes political reconciliation as a long-term social and inclusive process, which is designed to transform the unhappy co-existence of the parties to the conflict into a common political participation in public institutions and political processes through the gradual education of respect for both new institutions and former enemies. The four components of reconciliation - peace, justice, truth and forgiveness - must be interconnected in this process. As a result of the study, the author determines the obligatory elements of the interaction between the parties during and after the violent conflict, socio-psychological means of perception and interpretation of the past and future, the development of positive relations and reformatting them cultural and value paradigm, as well as the transformation of socio-economic reality. The conclusions revealed that the ideal model or perfect method of reconciliation after a violent conflict does not exist, therefore, in each particular case, the particularities of reconciliation vary, depending on the ability of the parties to creatively and effectively approach the process of reconciliation, from their ability to assume consistently the loss, cruelty and pain of the past for the sake of prospects for a common future. At the same time, the author comes to the conclusion that the prospects of reconciliation during and after the end of the violent conflict are determined by the practical manifestation of cooperation and the creation of reliable safeguards against the recurrence of the conflict in the future in order to build sustainable and lasting positive peace between the parties.

Key words: conflict; reconciliation; political process; peace building; society; violence. 
Семчинский Константин Валерьевич, кандидат философских наук, доцент, Киевский университет культуры, г. Киев, Украина

\section{Особенности примирения и его перспективы на разных стадиях насильственных конфликтов}

Определение перспектив примирения на разных стадиях насильственного конфликта возникает пока актуальных вопросов, поскольку уже во время конфликта закладываются основы пост-конфликтного урегулирования, от которого зависит эффективность примирения и возможность развития мира в будущем. Целью работы является исследование особенностей взаимодействия как между сторонами в течении глубинного межгосударственного конфликта, так и между сторонами в течении гражданского конфликта в пределах государства. Применив системные, аналитические и компаративные методы, автор характеризует политическое примирение как долговременный общественно-инклюзивный процесс, который призван трансформировать недовольное сосуществования сторон конфликта в общее политическое участие в общественных институтах и политических процессах посредством постепенного воспитания уважения, как к новым институтов, так и к прежним врагам. Четыре составляющие примирения - мир, справедливость, правда и прощения, - должны быть взаимосвязаны в этом процессе. В результате исследования автор определяет обязательными элементами взаимодействия между сторонами в течение и после насильственного конфликта общественно-психологические средства восприятия и трактовки прошлого и будущего, развитие позитивных отношений и переформатирование в них культурно-ценностной парадигмы, а также трансформацию социально-экономической реальности. В выводах обнаружено, что идеальной модели или совершенного метода примирения после насильственного конфликта не существует, поэтому в каждом конкретном случае особенности примирения различаются в зависимости от способности сторон творчески и эффективно подходить к процессу примирения, от их способности консолидировано принять потери, жестокость и боль прошлого ради перспектив общего будущего. В то же время, автор приходит к выводу о том, что перспективы примирения в течение и после завершения насильственного конфликта определяются практическим проявлением сотрудничества и созданием надежных предохранителей против рецидива конфликта в будущем для развития устойчивого и длительного положительного мира между сторонами.

Ключевые слова: конфликт; примирение; политический процесс; развитие мира; общество; насилие. 


\section{Семчинський Костянтин Валерійович \\ Особливості примирення та його перспективи \\ на різних стадіях насильницького конфлікту}

\section{Вступ}

Після закінчення холодної війни природа насильницького конфлікту зазнала суттєвих трансформацій. Всупереч попередній домінантній моделі, коли конфлікти відбувалися здебільшого між окремими державами, в останні десятиріччя набуває поширення гібридна модель, за якої держава-агресор інспірує та підживлює жорстокі конфлікти, що ззовні можуть видаватися внутрішнім протистоянням у державі, яка зазнала гібридної агресії. Постає актуальним дослідити особливості взаємодії не тільки і не стільки між сторонами глибинного міждержавного конфлікту, але між штучно розділеними в постраждалій державі сторонами впродовж і після насильницького конфлікту та перспективи примирення на різних його стадіях, оскільки врахування цих аспектів визначатиме ефективність пост-конфліктного врегулювання, примирення та можливість розбудови миру у майбутньому.

\section{Аналіз останніх досліджень і публікацій}

у дослідженнях і публікаціях зарубіжних дослідників було започатковано розв'язання цієї проблеми як в теоретичному, так i в практичному вимірі, як на суспільному, так і на міжнародному рівні. Останні вітчизняні публікації стосуються здебільшого практичного виміру врегулювання насильницького конфлікту, пост-конфліктного відновлення, а примирення розглядається крізь призму військово-стратегічних і політичних прерогатив. завдання:

Виходячи із викладеного вище, автор ставить перед собою такі

- дати характеристику примиренню як процесу трансформації суспільних відносин між конфліктуючими сторонами;

- визначити перспективи примирення на різних стадіях насильницького конфлікту задля розбудови тривалого позитивного миру;

- виявити елементи взаємодії між сторонами впродовж і після насильницького конфлікту, які є обов'язковими для ефективного примирення у майбутньому.

\section{Виклад основного матеріалу}

Життєвий цикл конфлікту можна поділити на три фази - до насильства, під час насильства і після насильства, які відокремлюють одну від одної початок кровопролиття і припинення вогню. Це не означає, що насильства не можна уникнути взагалі, i що конфлікт неминуче супроводжується насильством і руйнацією. Водночас, саме застосування насильницьких методів у протистоянні часто стає відправною точкою власне конфлікту, його точкою неповернення, яка ділить історію на «до» і «після». Так сталося взимку 2014 p. в Києві, коли ненасильницький протест за суспільні зміни перекинувся після перших смертей на безкомпромісне криваве протистояння, в якому апріорі міг 
бути тільки один переможець. Водночас, припинення бойових дій і кровопролиття відкриває шлях до примирення і розбудови миру.

Серед дослідників відсутня одностайність у визначенні примирення, оскільки воно одночасно є і метою - чого треба досягти - і процесом - тобто засобом досягнення мети. Багато непорозумінь виникає через суперечність цих підходів. Ми зосереджуємо свою увагу на примиренні як процесі. Мета примирення як процесу - це рух у напрямку до реального замирення, прагнення дійти ідеального стану миру, якого годі досягти у найближчій перспективі. Примирення-процес започатковується в умовах нинішнього (далекого від ідеального) стану і впроваджує практичні кроки для отримання невеликих поступових перемог у справі замирення; процес примирення безцінний тим, що в цей час закладаються основи примирення і поступово розбудовується практичний та ефективний шлях до кінцевої мети.

Відправною точкою процесу примирення є розуміння принаймні однією із сторін конфлікту неминучості його завершення і необхідності належним чином підготуватися до взаємодії із іншою стороною після його завершення. Примирення може відбуватися на різних щаблях в залежності від характеристик того чи іншого конфлікту - між державами, суспільними чи етнічними групами, політичною елітою і громадянським суспільством тощо. До того ж відданість процесу примирення та готовність до його втілення в різних сегментах суспільства можуть значно відрізнятися: під час умовного міждержавного конфлікту фінансово-промислові групи з обох сторін можуть активізувати зусилля із примирення задля інтересів бізнесу, в той час, як державний апарат жодної із сторін ще не створив комплексної стратегії пост-конфліктної відбудови і примирення. Або ж військові змушені завершувати конфлікт під тиском громадянського суспільства, яке, на відміну від них, вже готове примиритися із колишніми ворогами. Опиратися політиці примирення можуть і ті, хто безпосередньо постраждав унаслідок насильства. Втім, непоодинокими у світовій політиці сучасності $\epsilon$ і випадки, коли на побутовому рівні примирення відбувається всупереч конфлікту, що триває на рівні офіційному, державно-політичному.

Примирення - це процес, який включає пошуки правди й справедливості, прощення, відновлення довіри тощо. У найпростішій формі він окреслює шлях до життя поряд із колишніми ворогами - не обов'язково люблячи їх, чи прощаючи їх, чи забуваючи минуле, але співіснувати з ними, розвинути певний ступінь співпраці, необхідний для існування в одному суспільстві. Це тип компромісу. Проте «примирення не слід рекламувати як прагнення до щасливого і гармонійного співіснування колишніх ворогів. Це лише засіб досягнення певної міри наративної узгодженості перед лицем злодіянь, це зовсім інше, ніж полюбити свого мучителя, забувши і пробачивши 


\section{Семчинський Костянтин Валерійович \\ Особливості примирення та його перспективи \\ на різних стадіях насильницького конфлікту}

йому злодіяння» (Dwyer, 2003, p. 108) . До того ж, визначення примирення як відновлення коректних стосунків між людьми не повинно трактуватися як відновлення стосунків, що існували до початку конфлікту. Навпаки, мова йде про відновлення трансцендентального платонівського концепту справедливості (як найвищої правової та морально-етичної цінності) й встановлення коректних взаємостосунків, що грунтуються на конкретних нормах поведінки.

Особливості примирення на до-насильницькій стадії протистояння тісно пов'язані із проблематикою профілактики та попередження конфліктів. Пошуком компромісу в спірному питанні, у стосунках між сторонами загалом задля уникнення кровопролиття можуть займатися як уповноважені або ініціативні групи від кожної із сторін, так і медіатори - незаангажовані, або ж такі, які мають зацікавленість у вирішенні конфлікту на користь однієї із сторін. На стадії насильницького протистояння ідеї примирення із ворогом зазвичай не користуються популярністю, але універсального і простого плану примирення не існує в принципі. Адже не можна скоротити шлях чи знайти простий рецепт для загоєння ран та подолання розбрату в суспільстві після тривалого насильства. Відновлення довіри та порозуміння між колишніми ворогами $є$ надзвичайно важким завданням. Групи чи особи, що ініціюватимуть примирення у подібній ситуації, мають чітко розрізняти та виокремлювати проблеми політичного чи військового протистояння, які призвели до насильства, від перспектив неминучого пост-конфліктного примирення, врегулювання і відбудови. Адже політика - це процес навігації між проблемами, які розділяли сторони у минулому і можливо продовжують розділяти сьогодні. Примирення - це паралельний процес, який не стільки перекроює стосунки між сторонами, скільки будує між ними мости, відкриває можливості до спілкування і є дороговказом до майбутнього загоєння ран, відновлення довіри та залагодження стосунків. Якщо сторони насильницького конфлікту спроможні побудувати нові стосунки, які спиратимуться на повагу до потреб, співчуття до страхів та прийняття до зважання прагнень кожної із сторін, на розуміння форм, моделей та правил майбутньої співпраці, - це стане найкращим запобіжником насилля та розбрату. Встановлення таких стосунків - непросте завдання, оскільки будується воно, насамперед, за умов недовіри, нерозуміння (часто активного небажання зрозуміти), відсутності співчуття та переконання у власній правоті; перетворення таких негативних умов на позитивні чи хоча б нейтральні вимагає часу та зусиль, проте ці зусилля принесуть нагороду - ефективне примирення - і це найкраща гарантія того, що жорстокості минулого не повторяться. Отже, примирення це процес, завдяки якому суспільство переходить від розділеного минулого до спільного майбутнього. Головним завданням політики цього часу має стати визначення 
такого спільного майбутнього, домовленість між сторонами про його основні компоненти, та поширення в масах ідеї такого майбутнього як загальносуспільного бажаного ідеалу.

Примирення (як процес) ніколи не буває теоретичним питанням, воно завжди відбувається в конкретних умовах. Примирення в різних умовах, різних країнах, різних ситуаціях вимагає індивідуального підходу, не існує такого єдиного плану, такого рецепту успіху, стандартної формули примирення, які можна було б застосувати у конфліктах по всій земній кулі. Кожний конфлікт відрізняється від інших, як і кожна мирна угода відрізняється одна від одної, різняться політичні системи держав, їхня історія та національні характери народів. Різними були умови, які привели до конфлікту, тому і процес примирення щоразу буде відрізнятися у всіх важливих аспектах, навіть якщо, порівнюючи окремі випадки, ми знайдемо деякі подібності, характерні риси, виділимо типи, за якими може відбуватися процес примирення.

Одним із визначальних факторів примирення на завершальному етапі конфлікту дослідники відзначають елемент балансу влади між попереднім режимом та його наступниками у момент переходу. Три типові сценарії окреслюють варіанти перспектив пост-конфліктного примирення і розбудови миру. За першим сценарієм попередній режим гноблення було насильно і повністю повалено, або ж громадянська війна закінчилася вирішальною військовою перемогою однієї із сторін (показовим у цьому відношенні може бути кінець режиму Менгісту в Ефіопії у 1991 р.). За другим сценарієм перехід відбувається за ініціативи реформаторів у межах попереднього режиму, а політична еліта ініціює падіння режиму та відіграє в цьому процесі чи не вирішальну роль (так, наприклад, сталося у колишньому Радянському Союзі). За третім сценарієм перехідний період може бути результатом спільної дії, зокрема й досягнення домовленостей у переговорах між колишнім урядом та опозиційними групами. Сили попереднього режиму не повністю втратили владу, але й повстанці не отримали абсолютного контролю. Замість цього, у новому контексті, кожний аспект життя має бути обговорений між ними в результаті переговорного процесу (ми спостерігали такі процеси у Південній Африці та багатьох латиноамериканських країнах).

Кожний із цих типів перехідного періоду певною мірою підтримуватиме процес примирення. Кожний породить різні способи, як вчинити із спадщиною минулого. Перший сценарій - повалення деспотичного режиму - може сильніше заохочувати до карального правосуддя. Другий - внутрішні реформи - може спонукати до кроків з метою самозахисту у напрямку до амністії. Третій, де мир досягнуто в результаті переговорів, може відкрити можливості для процесу примирення, сформованому у переговорах між рівними. У цьому випадку, однак, одна сторона може прагнути амністії для свої 


\section{Семчинський Костянтин Валерійович \\ Особливості примирення та його перспективи \\ на різних стадіях насильницького конфлікту}

членів і прихильників ціною згоди підтримувати співіснування, в той час, як інша сторона може вимагати правосуддя та покарання як ціну своєї підтримки. Без абсолютного контролю жодна із сторін не досягне в цьому своєї мети без певних компромісів. Такий баланс важливий, оскільки досягнутий в результаті переговорів компроміс підтримує, або принаймні не перешкоджає процесу довготривалого примирення. Якщо ж переговори просто надають перемогу одній із сторін, виснажливе затамоване обурення, яким би прихованим воно не було, вірогідно перешкоджатиме примиренню на пізніших стадіях - і врешті знову може привести назад до конфлікту та нового насилля. Варто зауважити, якщо перехідний період призведе до нового всесильного режиму, це також впливатиме на процес примирення.

У пост-конфліктний період відбувається процес поступової перебудови широких соціальних відносин між громадами, розділеними постійним і поширеним насильством паралельно із обговоренням перспектив, реалій та компромісів нової, спільної соціально-політичної реальності. На завершальному етапі конфлікту - після роззброєння воюючих сторін та реінтеграції колишніх комбатантів у цивільне життя, відновлення інфраструктури, повернення біженців і переміщених осіб - сторони мають розбудувати таку систему відносин, яка б убезпечувала їх від рецидиву конфлікту у майбутньому. Саме на таку систему вказував Й. Галтунг, обгрунтовуючи поняття «негативного миру» - як простого припинення насильства - i «позитивного миру» - тобто створення таких механізмів і структур, за яких конфлікти або взагалі не виникають, або врегульовуються на ранній стадії (Galtung, 1995).

У цьому контексті постає завдання звернутися до процесу побудови тривалого і саме позитивного миру. Найкращий спосіб гарантувати, що конфлікт ніколи не повториться знову - це вивчати болісне минуле, визнаючи його та розуміючи його, і - найголовніше - переступаючи за його межі. Дж.П.Ледерак виокремлює чотири компоненти примирення - мир, справедливість, правда і прощення, які мають бути обов'язково взаємопов'язані в рамках процесу примирення. «Єдиним найбільшим викликом усіх конфліктів, особливо тих, що мають довгу історію насильства і страждань, є створення соціального простору, де можна тримати разом у взаємній залежності, не відокремленими та ізольованими, імпульси цих чотирьох соціальних енергій. Там, де вони поєднуються, пов'язуються між собою і взаємодіють, ми створюємо шлях, який веде до примирення. Там, де вони ігноруються, відокремлені один від одного, або ж не збалансовано представлені через обирання між ними кращого, ми часто не можемо створити стійкі мирні процеси» (Lederach, 2001, p. 848). 
У тому, що сьогодні називають «пост-конфліктні суспільства», загальна практика така, що ворогуючі сторони домовляються до врегулювання у формі нових структур правління. Майже завжди ці структури демократичні. Таким чином, колишні вороги - часто з давньою історією насильства між ними зіштовхуються 3 проблемами втілення нових структур, про які досягнуто домовленості, для майбутнього урегулювання їх відмінностей на основі мінімального співробітництва. Найбільша перешкода такому співробітництву це те, що (через насильство у минулому) їх стосунки засновані на антагонізмі, недовірі, відсутності поваги і, можливо, болю та ненависті. Це навряд чи додає оптимізму, незалежно від того, наскільки ефективними чи досконалими можуть бути ці нові структури.

Функціонуюча демократія заснована на подвійному фундаменті: (1) системі справедливих процедур для мирного улагодження тих питань, які поділяють суспільство (політичні та соціальні структури управління), і (2) системі стосунків співпраці між групами, що беруть участь у вирішенні конфлікту. Суспільство не розвине стосунків співпраці, якщо структури несправедливі, і навпаки, структури не зможуть правильно функціонувати, незважаючи на те, що вони справедливі i чесні, якщо нема мінімуму співробітництва у взаємостосунках тих, хто бере участь у вирішенні конфлікту.

Водночас у зонах колишнього конфлікту необхідно забезпечити правопорядок через такі урядові структури, які створені в процесі переговорів для улагодження суперечностей мирним шляхом. Сьогодні найпоширенішим способом для створення таких структур є демократична основа і принцип поваги до прав людини.

Забезпечення дотримання прав людини у пост-конфліктний період $€$ надзвичайно важливим елементом примирення. Коли універсальні права людини все ширше й більше приймаються як центральний принцип управління, демократія стає найефективнішим способом втілення демократичних принципів - рівності, відповідальності, участі в управлінні усіх верств населення.

На пост-конфліктній стадії може виникнути необхідність у залученні допомоги щодо розбудови демократії; така допомога може полягати у відновленні політичної системи суспільства після насильницького конфлікту місцевими силами, або ж у тимчасовому керуванні встановлення засад демократії міжнародними наддержавними структурами на кшталт ООН. Демократичний процес та структури самі по собі $є$ найбільш ефективними засобами для мирного запобігання та умілого управління конфліктом, особливо на пост-конфліктній стадії, коли важливо. Насамперед, створити механізми, спроможні запобігти поверненню до жорстоких дій у минулому. Процес примирення у конкретній пост-конфліктній ситуації має бути 


\section{Семчинський Костянтин Валерійович \\ Особливості примирення та його перспективи \\ на різних стадіях насильницького конфлікту}

розроблений таким чином, аби уникнути несправедливості та відповідати вимогам мирних угод. До того ж, у його розробці мають взяти участь усі сторони - це допоможе розвинути робочі стосунки в нових умовах постконфліктного періоду, розробити спільне бачення майбутнього, і таким чином підтримати молоді демократичні структури.

Процес примирення на пост-конфліктній стадії, зазвичай, складається 3 п'яти взаємопов'язаних елементів.

1. Розробка спільного бачення взаємозалежного та справедливого суспільства та спільного майбутнього, що вимагає залучення всього суспільства на всіх рівнях. Хоча індивіди можуть мати різні думки або політичні переконання, вираження спільного бачення взаємозалежного, справедливого, відкритого і безпечного суспільства є важливою частиною будь-якого процесу примирення.

2. Визнання минулого та ставлення до нього: правдивого визнання болю, втрат і страждань у минулому кожною із сторін вкупі з розвінчуванням міфів. Забезпечення механізмів правосуддя, оздоровлення, реституції або відшкодування, а також відновлення (включаючи вибачення, якщо це необхідно, та кроки, спрямовані на відшкодування збитків). Для розбудови примирення особи та інституції повинні визнати свою власну роль у конфліктах минулого, діяти конструктивно і забезпечити створення надійних запобіжників проти рецидиву конфлікту у майбутньому.

3. Розбудова позитивних відносин: побудова відносин або відновлення після насильницького конфлікту, що стосується питань довіри, упередженості, нетерпимості в цьому процесі, що призводить до прийняття спільності та відмінностей, а також охоплює та взаємодіє з тими, хто відрізняється від нас.

4. Значні зміни в культурі та ставленні до людей. Культура підозри, страху, недовіри і насильства мусить поступитися місцем відкритим можливостям і строкатому культурному простору, в якому люди можуть почути інших і бути почутими. Культура поваги до прав людини та людських відмінностей розвивається, створюючи контекст, де кожен громадянин стає активним учасником суспільства і відчуває почуття приналежності до розбудови позитивного миру.

5. Суттєві соціальні, економічні та політичні зміни: соціальні, економічні та політичні структури, які породжували конфлікт і відчуженість, були ідентифіковані, реконструйовані або розглянуті і трансформовані (Hamber, Kelly, 2004).

Політичне примирення починається 3 невдоволеного співіснування сторін конфлікту, і за допомогою поступового виховання поваги як до нових інституцій, так і до колишніх ворогів, покликано розвинути звичку спільної участі в суспільних інституціях і політичних процесах. 


\section{Висновки і пропозиції}

Варто розглянути питання примирення як процес трансформації суспільних відносин між конфліктуючими сторонами, що може детермінувати прагнення щодо врегулювання конфлікту і розбудови стійкого й тривалого позитивного миру. Ідеальної моделі чи досконалого методу примирення після насильницького конфлікту не існує, тому в кожному конкретному випадку особливості примирення залежать від здатності сторін творчо та ефективно підходити до процесу примирення, від їхньої здатності консолідовано прийняти втрати, жорстокість і біль минулого задля перспектив спільного майбутнього. Примирення повинно розглядатися як довготривалий процес, який може відбуватися десятиліттями упродовж багатьох поколінь.

Перспективи примирення у різні періоди насильницького конфлікту визначаються практичним проявом співробітництва та створенням надійних запобіжників проти рецидиву конфлікту в майбутньому. Ефективне примирення передбачає відхід від вирішення конфлікту за схемою «перемогапоразка» (хтось виграв, а хтось програв) до формули вирішення за схемою «всі у виграші».

Обов'язковими елементами взаємодії між сторонами впродовж і після насильницького конфлікту $\epsilon$ суспільно-психологічні засоби сприйняття і трактування минулого та майбутнього, розбудова позитивних відносин і переформатування в них культурно-ціннісної парадигми, а також трансформація соціально-економічної реальності.

\section{References:}

1. Galtung, J. (1995). 'Kul'turnoe nasilie' [Cultural violence]. Sotsial'nye konflikty: ekspertiza, prognozuvannya, tekhnologï dozvolu [Social conflicts: expertise, forecasting, technology solutions], issue 8, pp. 34-38.

2. Dwyer, S. (2003). 'Reconciliation for Realists'. Dilemmas of Reconciliation: Cases and Concepts. Waterloo, Ontario, Wilfrid Laurier University Press.

3. Hamber, B., Kelly, G. (2004). 'A Working Definition of Reconciliation'. Community Relations Council, [online]. Available at: https://www.communityrelations.org.uk/publications/working-definition-reconciliation-0

[Accessed 07 February 2019].

4. Kelman, H. C. (2010). 'Conflict Resolution and Reconciliation: A SocialPsychological Perspective on Ending Violent Conflict Between Identity Groups'. Landscapes of Violence, vol. 1, no. 1, article 5, [online]. Available at: <http://dx.doi.org/10.7275/R5H12ZX0 > [Accessed 28 February2019].

5. Lederach, J. P. (2001) 'Civil Society and Reconciliation'. Turbulent Peace: the Challenges of Managing International Conflict. Washington DC, USIP. 
6. Philpott, D. Powers, G. F., eds. (2010). Strategies of Peace. Transforming Conflict in a Violent World. New York, Oxford University Press.

(C) Семчинський К. В., 2019 